\title{
Canis lupus - dziki i oswojony, realny i antropomorfizowany, czyli ponad sto lat wilka w literaturze dziecięcej i młodzieżowej (wybrane problemy) ${ }^{1}$
}

\section{Abstrakt:}

Przedmiotem artykułu jest analiza przekształceń, którym poddawany jest gatunek Canis lupus w wybranych dziełach literatury dziecięcej i młodzieżowej. Autorka tekstu podejmuję próbę wyjścia poza perspektywę antropocentryczną w celu wskazania, w jaki sposób cechy uznawane w kulturze za wilcze przyczyniają się do kreowania ogólnego wizerunku wilka jako zwierzęcia wchodzącego w relację $\mathrm{z}$ dziecięcym bohaterem literackim. Motywy i zabiegi artystyczne omówione w artykule, takie jak nawiązywanie relacji z człowiekiem, oswajanie czy antropomorfizacja, ukazują oblicze granicy natura - kultura z jednoczesnym podkreśleniem jej problematycznego położenia. Naczelny materiał badawczy stanowią utwory Szara Wilczyca Jamesa Olivera Curwooda (1914), Wilczerka Katherine Rundell (2015) oraz Czerwona baśń Wiktorii Korzeniewskiej (2020), a kontekstowo przywołane zostają wybrane baśnie tradycyjne i inne teksty kultury dziecięcej i młodzieżowej.

\section{Słowa kluczowe:}

antropomorfizacja, baśń, Czerwona baśń, drapieżnik, dzikość, James Oliver Curwood, Katherine Rundell, literatura dziecięca i młodzieżowa, oswajanie, Szara Wilczyca, Wiktoria Korzeniewska, Wilczerka, wilk

* Aleksandra Butrymowicz - lic., przygotowuje pracę magisterską na Wydziale „Artes Liberales" Uniwersytetu Warszawskiego dotyczącą postaci zwierzęcych w literaturze dziecięcej i młodzieżowej. Kontakt: a.butrymowicz@student.uw.edu.pl.

1 Artykuł stanowi zmodyfikowaną wersję pracy licencjackiej Sto lat wilka w literaturze dziecięcej i młodzieżowej. Analiza porównawcza wizji wilka w Szarej Wilczycy Jamesa Olivera Curwooda oraz Wilczerce Katherine Rundell (2020) napisanej w ramach studiów na kierunku antropozoologia na Wydziale „Artes Liberales” Uniwersytetu Warszawskiego. Pragnę podziękować Pani Promotorce, prof. dr hab. Katarzynie Marciniak, za cenne wskazówki dotyczące zarówno samej pracy dyplomowej, jak i niniejszego artykułu. 
Canis lupus - Wild and Tame, Real and Anthropomorphised, or Over a Hundred Years of a Wolf in Children's and Young Adult Literature (Selected Problems)

\section{Abstract:}

The aim of the article is to analyse the metamorphoses which the Canis lupus species is subjected to in selected examples of children's and young adult literature. The author of the paper attempts to go beyond the anthropocentric perspective in order to show how the features considered in culture as wolfish contribute to the creation of the image of the wolf as an animal entering into a relationship with a particular book's child character. The motifs and artistic devices discussed in the article, such as establishing human-animal relationships, taming, or anthropomorphisation, show the face of the nature-culture border while emphasising its problematic location. The main research material consists of Kazan by James Oliver Curwood (1914), The Wolf Wilder by Katherine Rundell (2015), and Czerwona baśń [A Red Fairy Tale] by Wiktoria Korzeniewska (2020), with contextual references to selected traditional fairy tales and other cultural texts for children and young people.

\section{Key words:}

anthropomorphisation, fairy tale, Czerwona baśń, predator, wildness, James Oliver Curwood, Katherine Rundell, children's and young adult literature, taming, Kazan, Wiktoria Korzeniewska, The Wolf Wilder, wolf

\section{Wprowadzenie}

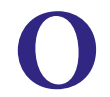

d tysiącleci społeczeństwa ludzkie tłumaczyły sobie prawa rządzące rzeczywistością, odwołując się do świata zwierząt - m.in. drapieżników, takich jak wilki. O ile w krajach Orientu przez stulecia te ssaki pełniły funkcję opiekuńczą, a więc były odbierane pozytywnie, o tyle na chrześcijańskim Zachodzie zdecydowanie przeważał ich krzywdzący obraz jako bestii. Michał Nikodem (2014, s. 273-274) pisze, że zła sława Canis lupus w schrystianizowanej Europie miała związek m.in. $\mathrm{z}$ utożsamianiem go $\mathrm{z}$ dwoma grzechami głównymi: chciwością i nieumiarkowaniem w jedzeniu i piciu (dodatkowo, średniowieczne wyobrażenie wilka jako diabła i heretyka umieściło go w opozycji do baranka, symbolu wiary, w jeszcze większym stopniu podkreślając jego naturę drapieżnika).

Nie ulega jednak wątpliwości, że wilk, pomimo strachu, który wywołuje, a być może właśnie za jego sprawą, jest współcześnie zwierzęciem stanowiącym nierzadko obiekt fascynacji. Wachlarz wzbudzanych przez ten gatunek głębokich emocji, takich jak strach i admiracja, przemożnie działał na ludzką 
wyobraźnię, czego efektem było powstanie wielu dzieł literackich. Często, z jednej strony, „krzywdziły” one wilka, ukazując go w negatywnym świetle, z drugiej zaś - przedstawiały go jako istotę majestatyczną, magiczną (Sieroń, 2005), a co najmniej godną podziwu. Można zaryzykować stwierdzenie, że „kulturowa nagonka"2 na wilki była zarówno następstwem strachu przed nimi, jak i późniejszą przyczyną owego strachu. Zjawisko to mogło mieć również wpływ na nadanie wilkom statusu zwierząt „śmieciowych”. Ewelina Rąbkowska (2016) pisze, że:

[...] uznawanie wilków za „śmieciowe" może się wiązać z odczuwanym przez człowieka lękiem przed tym, co uosabiają te zwierzęta: dzikością, wolnością, pożądaniem, głodem. Strach ten jest m.in. przyczyną irracjonalnego okrucieństwa wobec zwierząt pojmowanych jako „śmieciowe” (s. 34).

Cechy, które posiadał i wciąż, mimo upływu lat, posiada literacki wilk, mogą być - w zależności od wielu różnych czynników - postrzegane jako pożądane bądź niepożądane. W tekście skupiam się kolejno na trzech głównych kwestiach bezpośrednio wynikających $\mathrm{z}$ kulturowej interpretacji wilczej natury: na więzi wilka $\mathrm{z}$ bohaterem dziecięcym, na zjawisku oswajania (które w przypadku wilka bywa zarówno dosłowne, jak i symboliczne) oraz na antropomorfizacji zwierząt. Jednocześnie staram się ukazać problematyczną granicę między tym, co ludzkie, a tym, co zwierzęce. W tym celu omawiam klasyczną powieść Szara Wilczyca Jamesa Olivera Curwooda (1914/1961) oraz nowsze utwory: Wilczerkę Katherine Rundell (2015/2019) i Czerwona baśń Wiktorii Korzeniewskiej (2020). Kontekstowo wykorzystuję także wybrane tradycyjne baśnie oraz inne teksty kultury dla dzieci i młodzieży wykorzystujące postać wilka.

\section{Wilczy bohater literacki}

W literaturze dziecięcej i młodzieżowej wilk jawi się w sposób niejednoznaczny. Można powiedzieć, że gdy zostaje zaprezentowany w wierszu dla najmłodszych czy w powieści dla starszych dzieci, prawie nigdy nie jest „tylko” wilkiem, toteż ten drapieżny ssak, przodek naszych współczesnych psów domowych, staje się przede wszystkim wykreowanym przez autora obrazem - reprezentacją

2 Określenie „kulturowa nagonka” wynika z analogii do zjawiska polowania i w odniesieniu do wilka nie jest bezpodstawne. Uporczywe dążenie społeczeństw do wytępienia tego gatunku to wynik nieuzasadnionego, często sprzecznego $\mathrm{z}$ wiedzą na temat tego zwierzęcia strachu przed nim. 
ludzkich wyobrażeń. Jednym z czynników wpływających na literackie wizerunki wilka jest funkcja, którą pełni dany tekst, oraz gatunek, jaki reprezentuje. Fakt, czy jest to edukacyjny picturebook (np. Wilk, który się zgubił autorstwa Rachel Bright i Jima Fielda, 2018/2019), czy powieść przygodowa (A Wolf Called Wander [Wilk zwany Łazęgą] Rosanne Parry, 2019), ma znaczenie w doborze cech składających się na poszczególne obrazy wilka. Stworzona dla najmłodszych książka obrazkowa wspomaga rozumienie otaczającego świata i kształtuje wrażliwość czytelnika. Wilczy bohater bywa poddawany juwenalizacji, a przez to - dostosowywany do wieku odbiorcy. Zdarza się, że złagodzona zostaje również jego drapieżnicza natura - na rzecz stosowania diety roślinnej (Wilczek Gerdy Wagener, 1993/2007). Wilk, którego przygody obserwujemy w powieściach przygodowych, cechuje się nierzadko wyjątkową wytrwałością i odwagą, jak Kazan, bohater książki Curwooda. Na przykładzie ostatniej wymienionej pozycji literackiej widać również, że przy kreowaniu tekstu w grę wchodzić może sytuacja, która oddziaływała lub oddziałuje na określonego autora, decydująca ostatecznie o wydźwięku dzieła³.

Pamiętając, że granica między literaturą dziecięcą a młodzieżową jest dość płynna (Baluch, 1993, s. 7), można zauważyć, że wilczy bohater w utworach dla najmłodszych, jak wiersz Zoo Jana Brzechwy (1938/2014), to często uosobienie czyhających na kilkuletniego człowieka niebezpieczeństw. Podobnie jest w tradycyjnych baśniach ${ }^{4}$ - warto w tym kontekście przywołać te najpopularniejsze z nich, które wykorzystują postać wilka, znane powszechnie w świecie zachodnim dzięki wersjom braci Grimmów (1857/2010a, 1857/2010b), czyli Czerwonego Kapturka oraz $O$ wilku i siedmiu koźlątkach (która reprezentuje ten sam typ co np. tradycyjna angielska opowieść Trzy małe świnki). Wilk baśniowy w ciekawy sposób odzwierciedla wcześniej przeze mnie przywołaną symbolikę chrześcijańską, wedle której Canis lupus nie jest w stanie pohamować się przed obżarstwem, a także cechuje się chciwością. W zależności od kodu kulturowego wilk mógłby zostać zastąpiony każdym innym gatunkiem utożsamianym

3 Pisarz poznawał dziką przyrodę i życie zwierząt, podróżując i obserwując życie traperów oraz poszukiwaczy złota, co wykorzystał w powieściach, nadając im realistyczny charakter (Curwood, 1914/1961, s. 383).

4 „W baśniach, mitach, legendach, snach, projekcjach środowiskiem tym [będącym eksterioryzacją strefy cienia] jest [...] las, gdzie cień ma zawsze charakter osobowy. W baśniowym imaginarium, w którym wszystkie mroczne fantazmaty wywiedzione są z demonologii ludowej, cień spersonifikowany jest w postaciach grozy, realizujących kanibalistyczną i nekrofiliczną tożsamość »wilka«: 1) drapieżnego zwierzęcia, 2) mordercy, 3) ludożerczyni/ dzieciojada, 4) monstrum humanum, [5]) istot antycypujących los ludzki po śmierci: kostuchy i diabła" (Slany, 2016a, s. 30; zob. także s. 53-103). 
w danej społeczności ze złem - w celu wyrażenia przestrogi przed zjawiskami znanymi dorosłym, ale już niekoniecznie dzieciom, a także jako alegoria ludzkich zachowań czy cech (Mikołuszko, 2016).

Nierzadko w literaturze dla starszych dzieci oraz młodzieży wilk zostaje „odczarowany” i za sprawą zabiegów tekstowych pozbywa się brzemienia istoty o znaczeniu alegorycznym (np. Biały Kieł Jacka Londona, 1906/2006). Zachodzi tutaj zjawisko oswajania strachu wywołanego przedstawianiem w złym świetle wilka, który w literaturze dla najmłodszych, dla przypomnienia, jest wielokrotnie zwierzęcym symbolem, alegorią, a nie wilkiem „jako takim”. Wilk "odczarowany” zostaje wyeksponowany jako zwierzę samo w sobie - takie, które nie jest złe z natury, nie jest też metaforą zła, ale (co jest bardziej zgodne $z$ aktualnym stanem wiedzy zoologicznej) jednostką kierującą się instynktami charakterystycznymi dla tego gatunku. Wilk w literaturze młodzieżowej, może także częściowo w dziecięcej ${ }^{5}$, to więc nie alegoria, wciąż jednak jego obecność w tekście służyć ma przedstawieniu uniwersalnych zjawisk społecznych czy emocjonalnych, takich jak przyjaźń ludzko-zwierzęca (np. Księga dżungli Rudyarda Kiplinga, 1894/2005, Wilczerka Rundell). Umieszczony pośród wydarzeń, wpływa na nie bądź one wpływają na niego. Jednak jego zachowania i reakcje są bliższe tym właściwym gatunkowi Canis lupus aniżeli baśniowym wilkom. Zamiłowanie do wolności i niezależności (które od wieków są nieprzychylnie interpretowane przez społeczeństwa ludzkie, ponieważ nie dają się uchwycić ani okiełznać) ma okazję wybrzmieć jako godne naśladowania.

Kreowanie obrazu „odczarowanego” wilka w literaturze, a więc wilka, który już nie jest stereotypem, lecz nośnikiem cech, w dodatku tych bardziej behawioralnie wilczych, jak tworzenie watah czy unikanie konfrontacji z człowiekiem (Nowak, Mysłajek, 2019, s. 8, 11), prowadzi niejednokrotnie do zaprezentowania $\mathrm{w}$ tekście specyficznej relacji z bohaterem ludzkim. Relacja z wilkiem zdaje się wpływać na zachowanie człowieka (zarówno dziecka, jak i dorosłego) w sposób mający ścisły związek z niezależną naturą tego zwierzęcia i z tkwiącym w bohaterze ludzkim ziarnem niezależności, które za sprawą odpowiedniego bodźca zaczyna kiełkować. Jednocześnie człowiek okazuje się wpływać na zachowanie wilka, oswajając go (i tym samym odbierając mu niezależność) bądź wręcz przeciwnie, o czym piszę w dalszych częściach artykułu.

5 Ponieważ granica pomiędzy literaturą dziecięcą a młodzieżową jest umowna, niektóre powieści, takie jak omawiana w dalszej części artykułu Wilczerka, trudno jednoznacznie zaklasyfikować do jednej kategorii bazującej na wieku hipotetycznych odbiorców. 


\section{Relacja wilka z bohaterem dziecięcym - przykład Wilczerki}

Liczne przykłady bohaterów zwierzęcych w literaturze dla najmłodszych to, zdaniem Rąbkowskiej (2017), „odbicie tego, iż dziecku przypisywane jest szczególne zainteresowanie innymi zwierzętami, że są one dla niego wyjątkowo atrakcyjne, nie tylko jako stały element jego otoczenia, dostarczając intensywnych bodźców poznawczych, ale jako istoty w pewien sposób bliskie jego umysłowości i wrażliwości” (s. 86). Autorka zauważa, że zwierzę towarzyszące bohaterowi dziecięcemu nie tylko pełni niezwykle ważną funkcję w jego rozwoju, lecz także w sposób "naturalny” staje się zarówno przyjacielem młodego człowieka, jak i swego rodzaju przewodnikiem, który ma wprowadzać go w świat dorosłych.

W celu ukazania specyfiki relacji dziecka i dzikiego zwierzęcia warto posłużyć się powieścią Rundell pt. Wilczerka. Autorka urodziła się w 1987 roku w Kent w Anglii, jednak dzieciństwo spędziła w Harare w Zimbabwe, gdzie jej ojciec był dyplomatą. Młode lata pisarki w Afryce wyglądały inaczej niż życie dzieci w Europie. Być może to sposób, w jaki spędzała czas po szkole (gdy wspinała się na drzewa i urządzała zawody pływackie z przyjaciółmi; „Katherine Rundell”, b.d.), był inspiracją dla postaci Fieodory (Fieo), którą Rundell stworzyła na potrzeby Wilczerki.

Wilczerka, w przeciwieństwie do takich powieści jak wspomniane już Szara Wilczyca Curwooda czy Biały Kieł Londona, nie ukazuje losów konkretnego wilka, lecz przybliża historię wilczerów i wilczerek [wolf wilders]. Fieodora jest jedną z nich, a wilki towarzyszą jej każdego dnia i swoją obecnością wpływają na rozwój akcji. Na podstawie ich zachowania główna bohaterka była w stanie przewidzieć nadejście burzy śnieżnej i tym samym zminimalizować jej skutki, a same wilki wielokrotnie ogrzewały ją swoją sierścią. Zadaniem wilczerów jest „odswajanie” wilków (czyli przywracanie im ich pierwotnej natury), a oswajanie tych stworzeń zostaje poddane szerokiej krytyce zarówno bezpośrednio, w odautorskim prologu, jak i pośrednio, poprzez prezentację działalności Fieodory i jej mamy w poszczególnych rozdziałach utworu. W powieści czytamy, że wilki, które miały to nieszczęście, że zostały schwytane przez gang handlarzy, są traktowane jak maskotki w domach bogatych Rosjan. Uczone siadać nieruchomo, karmione kawiorem, zyskują wartość symboliczną - mają przynosić szczęście. Jak jednak pisze w prologu Rundell (2015/2019):

[...] wilka nie da się oswoić tak jak psa, nie da się też trzymać go w domu. Wilki, jak dzieci, nie przychodzą na ten świat, by wieść spokojne życie, każdy z nich nieodmiennie zaczyna wariować w niewoli i w końcu odgryza i pożera kawałek 
osoby, która nie oczekuje, że zostanie pożarta. Wówczas pojawia się pytanie: co począć z wilkiem? (s. 8).

Pisarka eksponuje więc bezkompromisowość i czyni z niej wartość, która ma łączyć kulturowe wyobrażenie o Canis lupus z cechą, którą przypisuje się dzieciom. Umieszczenie takiego fragmentu już w prologu powieści sugeruje, że Rundell nie zamierza obarczać dziecięcej bohaterki brzemieniem grzecznej dziewczynki. Ma to niezwykle istotne znaczenie zarówno w walce o dobre imię wilka, jak i w walce z krzywdzącymi stereotypami, o tyle okrutnymi, że dotyczącymi już najmłodszych. Taka kreacja postaci, z jednej strony, wskazuje na potrzebę dowartościowania prawdziwych, behawioralnych cech wilka $\mathrm{z}$ perspektywy nieantropocentrycznej, a z drugiej - załamuje patriarchalny wymiar wychowania dziewczynki jako posłusznej, a więc w obu przypadkach podważa zasady dominującego dyskursu.

Samo zestawienie dzieci i zwierząt - tych pierwszych ukazywanych nierzadko, w opozycji do dorosłych, jako istoty, które za sprawą wychowania wyrwały się ze stanu „zwierzęcości” - to przedmiot analizy w ramach różnych dyskursów, a jednym ze znanych motywów literackich opartych na wyobrażeniach o relacji dziecka i zwierzęcia ${ }^{6}$ jest wychowanie młodego człowieka przez „dzikie” stworzenia (Skowera, 2016, s. 54). Relacja Fieodory z wilkami w Wilczerce przypomina $\mathrm{w}$ dużym stopniu właśnie ten sposób ukazywania związku między oboma typami bohaterów. Dziewczynka już na samym początku powieści zostaje rozdzielona $\mathrm{z}$ matką, a to oznacza, że zdana jest wyłącznie na siebie i wilki (a one są zdane na nią). Mamy zatem do czynienia nie tyle z wychowaniem dziecka przez dzikie zwierzę w tak dosłownym sensie, jak ma to miejsce np. w Księdze dżungli Kiplinga, ile ze wzajemną opieką, troską, a dopiero $\mathrm{w}$ efekcie $-\mathrm{z}$ wychowaniem w szerokim znaczeniu tego pojęcia.

Zestawienie wilków z dziećmi, które zastosowała Rundell, znacznie wykracza poza utarte schematy, którym ulegamy jako społeczeństwo przyzwyczajone do tradycyjnie demonizowanej postaci wilka. Stereotypowy wilk literacki to istota, której człowiek powinien się wystrzegać, bezkompromisowy drapieżnik, w swojej brutalności bardziej „Zwierzęcy” aniżeli „ludzki”. W przypadku tych określeń należy przede wszystkim pamiętać o nacechowaniu obu słów, gdzie „zwierzęcy” konotuje dzikość, a „ludzki” empatię i zasady moralne.

6 Dariusz Piechota (2018) pisze: „W niewyjaśniony sposób to właśnie najmłodsi [w literaturze] zyskują prawo wstępu do świata nie-ludzi, który wydaje się zamknięty przed ludźmi dorosłymi” (s. 125). 
Analizę Wilczerki warto wzbogacić o omówienie okładki. Pamiętać należy, że choć autor często nie ma wpływu (lub ma niewielki wpływ) na oprawę wizualną utworu literackiego ${ }^{7}$, to właśnie ona nierzadko kształtuje wstępny osąd odbiorcy o opowieści, która znalazła się w jego rękach. Tym, co w przypadku omawianej książki najszybciej przyciąga wzrok potencjalnego czytelnika, jest czerwona peleryna, która w pędzie powiewa na plecach małej dziewczynki siedzącej na grzbiecie wilka. Nietuzinkowa scena ma miejsce w lesie, pośród baśniowo zaśnieżonych drzew. $\mathrm{W}$ oddali, $\mathrm{w}$ prześwicie między świerkami, widnieje cerkiew, co zapowiada, że Rundell pragnie zabrać swojego odbiorcę do Rosji. Czy jednak piękny i magiczny krajobraz, a także niezwykła scena w centrum kompozycji, to jedyne baśniowe elementy? Sens całości tkwi w równej mierze w czerwonej pelerynie: dziewczynka z okładki, identyfikowana w trakcie lektury jako Fieodora, przypomina ubiorem Czerwonego Kapturka, którego kreację znamy z treści baśni Grimmów, jak również z wielu późniejszych wydań i adaptacji ilustrowanych - właśnie ze względu na ten element garderoby ilustracja nie pozostawia wątpliwości, z kim kojarzy się postać. Jednak tym, co może wprawić odbiorcę w zdumienie, jest kontrast między fabułą i znaczeniem opowieści o Czerwonym Kapturku a wizerunkiem na okładce Wilczerki. Kapturek miał się przecież wystrzegać złego wilka, a nie dumnie pędzić na jego grzbiecie przez ciemny las.

Fieodora nawiązuje zupełnie inną relację z wilkami niż tacy ludzie, którzy nie szanują ich dzikiej natury. Ma to związek z opisanym wyżej motywem literackim, którego istotą jest podobieństwo dzieci i zwierząt. Bohaterka dba o to, aby wilki mogły wrócić do niezbędnych adaptacyjnie zachowań, a dzięki temu - przeżyć. Spoczywa na niej nie lada obowiązek, musi bowiem nauczyć te zwierzęta na nowo dzikości. Sama Fieo, co nie ulega wątpliwości, zachowuje się trochę „wilczo”, co z pewnością pomaga jej w zdobyciu zaufania czworonożnych przyjaciół oraz $\mathrm{w}$ zrozumieniu ich potrzeb. Idzie tu jednak bardziej o tożsamość charakterów dziewczynki i wilków, a nie o celowe działanie z jej strony. Wilki akceptują Fieodorę i - mimo że zadaniem bohaterki jest nauczenie ich życia z dala od ludzi - łączy ją z nimi wyjątkowa więź. Są w stosunku do Fieo bardzo opiekuńcze, tak jak ona wobec nich. Dziewczyna w rezultacie uczy wilki, a także - co opisuję w kolejnej części artykułu - ludzi walczyć o swoje prawa, wolności i ideały.

Wyjątkami od tej reguły są picturebooki autorskie, gdzie twórca odpowiada za grafikę i tekst, oraz przypadki, gdy pisarz nawiązuje współpracę z ilustratorem oraz innymi osobami odpowiadającymi za oprawę graficzną. 


\section{Wilk oswojony - Szara Wilczyca i Wilczerka}

\section{dziki}

1. nieoswojony, występujący w środowisku naturalnym;

2. prymitywny, pierwotny, nieufny, nieokrzesany;

3. niezgodny z normami społecznymi, nieusankcjonowany prawnie („Dziki”, b.d.).

oswoić

1. przyzwyczaić do czegoś, zaznajomić;

2. obłaskawić, udomowić dzikie zwierzę („Oswoić”, b.d.).

Przywołane przeze mnie definicje mają na celu wskazanie raczej skojarzeń uwarunkowanych kulturowo niż sprecyzowanie natury stanów, jakimi są dzikość i oswojenie. Używam tych pojęć przeciwstawnie, co według definicji z tworzonego przez hobbystów popularnego internetowego Słownika sjp.pl - nieprofesjonalnego, ale dającego wgląd w potoczne rozumienie słów - wydaje się słuszne. O dzikości i o tym, co dzikie nie jest lub dzikie przestaje być (i kiedy tak się dzieje), powstają publikacje naukowe, ponieważ - jak się okazuje - pojęcia te są po pierwsze nadużywane, a po drugie dosyć złożone (Mittermeier, Mittermeier, Brooks, Pilgrim, Konstant, da Fonseca, Kormos, 2003). Na potrzeby analizy utworu literackiego, który wyrasta z uwarunkowań kulturowych i na przemiany kulturowe wpływa, wystarczą podane wyżej definicje, ponieważ używając terminów „dziki” czy „oswoić”, statystyczny czytelnik odwołuje się raczej do swoich skojarzeń, a nie do zagadnień filozofii środowiskowej.

Wilk, uosobienie dzikości, tak jak drapieżnictwo wydaje się nieokrzesany i brutalny. Pamiętajmy, że poruszamy się tu po nici skojarzeń. Tak więc las, a więc przestrzeń kulturowo powiązana $\mathrm{z}$ wilkiem, jest postrzegany jako miejsce złe, mroczne, wręcz jako włości Szatana (Jans, 2014/2016, s. 39). Czerwony Kapturek wystrzegać miał się lasu, w którym mieszkał zły wilk $^{8}$. W języku polskim natomiast mówimy np. „ciągnie wilka do lasu” czy

8 „W baśni magicznej przestrzenią exterior jest zawsze las - miejsce przynależne w tradycji wierzeniowej obłąkanym, obcym, czarownicom, mordercom, banitom, demonom, wilkom, czyli wszelkim istotom o destrukcyjnej tożsamości. Las jako przestrzeń graniczna jest miejscem transgresyjnym, symbolicznym i fantazmogennym, dlatego bohater nie istnieje w nim ani w świecie społecznym, ani w świecie zwierzęcym. W lesie dochodzi do głosu to, co zdaniem społeczeństwa jest tajemnicze, zakazane i rodzi się na gruncie potępienia oraz odrzucenia" (Slany, 2016b, s. 274). 
„nie wywołuj wilka z lasu”. Kulturowa wizja wilka i to, co kulturowo z wilkiem związane, ma więc skłaniać nas do postrzegania tych pięknych zwierząt w kategoriach dzikości, wraz ze wszystkimi negatywnymi konotacjami tego pojęcia. Oswojenie, zgodnie z przywołaną definicją, ma zaś być odejściem od stanu dzikiego, nierzadko za sprawą wpływów wewnętrznych czy zewnętrznych. W języku polskim „oswoić strach” czy „oswoić się z sytuacją” oznacza głębsze poznanie tego, co poprzez niedostatek wiedzy wydaje się niebezpieczne. Bez względu na kontekst, w jakim posługujemy się tymi zwrotami, mają one wspólny element - zakładają, że zagrożenie ze strony czegoś lub kogoś maleje, kiedy dochodzi do „oswojenia”. To, co nieznane („nieoswojone”), ma natomiast wywoływać strach.

Czym zatem są dzikość i oswojenie w kontekście wilczych bohaterów literackich? Aby zrozumieć, jak na fabułę dzieła literackiego wpływa to, czy wilk jest dziki, czy też oswojony, warto zwrócić uwagę na relację wilków z człowiekiem w Szarej Wilczycy Curwooda i Wilczerce Rundell. Zestawienie akurat tych powieści jest usprawiedliwione faktem, iż daty ich wydania dzieli ponad sto lat (dokładnie sto jeden) - to właśnie pozwala nie tylko na analizę zjawiska oswojenia dzikiego zwierzęcia, lecz także na wskazanie, jak zmienił się obraz wilka na przestrzeni wieku.

Kazan z powieści Curwooda, w trzech czwartych pies i w jednej czwartej wilk, to doskonały, wręcz modelowy literacki przykład balansowania pomiędzy stanem dzikim a oswojonym, wraz z ukazaniem wszelkich skutków zawieszenia między światem, w którym rządzą prawa przyrody, a tym, w którym rządzi człowiek. Kazan ma możliwość funkcjonowania w obu środowiskach, a więc czasem grzeje się przy ogniu wraz z ludźmi, a kiedy indziej przemierza dzikie tereny wraz z tytułową Szarą Wilczycą. Możliwość życia jako istota częściowo dzika, a częściowo oswojona, to wątpliwy przywilej. W rzeczywistości stanowi to bowiem ogromny problem dla Kazana, utrudnia mu określenie własnej przynależności. Funkcjonowanie w stanie i dzikim, i oswojonym ma wady i zalety. Kazan pod opieką ludzi otrzymuje co prawda dostęp do ciepła i pożywienia, jednak pod groźbą niesprawiedliwego traktowania i niebezpieczeństwa ze strony psów, które postrzegają go jako obcego. Co więcej, w lesie, dokąd wzywa Kazana tzw. „wilczy zew”, wraz z Wilczycą zwierzęcy bohater czuje się wolny, ale tęskni za ludźmi, zwłaszcza za tymi, którzy dali mu miłość. Kazan, jako półdziki, ma jednak przewagę zarówno nad wilkami, jak i nad psami. Siła jego szczęk pozwala mu, po wilczemu, bronić się przed atakami wrogo nastawionych psów, natomiast pełny żołądek i zregenerowany, wypoczęty organizm dają często przewagę nad wygłodniałymi wilkami skazanymi na walkę z innymi zwierzętami i siłami przyrody. 
Szara Wilczyca Curwooda, na przykładzie Kazana, ukazuje więc, jak silnie zakorzenione mogą być w żywej istocie oba stany - dzikości i oswojenia, co prowadzi do niemożności całkowitego wyrzeczenia się jednego z nich: dzikie zwierzę nigdy nie będzie w pełni oswojone, natomiast to, które udało się oswoić choćby w niewielkim stopniu, już nigdy nie będzie równe swoim dzikim odpowiednikom. Kontakt z dziką przyrodą, tak jak kontakt z ludźmi, zawsze zostawia trwały ślad. Jednocześnie, jak zauważa Anna Barcz (2015, s. 170), oswojenie może być traktowane jako przejaw dominacji człowieka nad zwierzęciem (badaczka, za Yi-Fu Tuanem, 1984/2007, wskazuje tu na źródłosłowy „udomowienia” i „zdominowania”). W przypadku Kazana wyraźna staje się zatem nie tylko trudność w dopasowaniu do sfery ludzkiej bądź zwierzęcej, lecz także niechęć do całkowitego poddania się człowiekowi. Bohater powieści Curwooda daje dowody sympatii względem życzliwych mu ludzi, przypomina to jednak relację „równego z równym” opartą na wzajemności.

Rundell w Wilczerce podejmuje zaś próbę przedstawienia stanu oswojenia jako swoistej skazy na dzikiej naturze wilka. Należy jednak mieć świadomość, że oswojenie u Curwooda wynika z kontaktu z człowiekiem, który pragnie wykorzystać właśnie dziką naturę wilka, dlatego też zależy mu na zachowaniu takich cech jak agresja czy siła (Kazan służy jako zwierzę do walk czy strażnik namiotu). U Rundell wilki zostają natomiast oswojone, aby stać się maskotkami bogatych Rosjan i stanowić dla nich pociechę. Szczenięta są więc odbierane matkom i celowo wychowywane na potulne i pocieszne, co znacznie utrudnia ich powrót do środowiska zarówno ze względu na brak umiejętności koniecznych do życia w naturze, jak i wskutek wyrządzonej im fizycznej krzywdy (przekarmienie).

Przedstawienie oswojonych wilków jako skrzywdzonych ma jednak uzasadnienie w kontekście fabuły książki. Kiedy wojska carskie palą dom Fieo i zabierają jej matkę do więzienia, dziewczynka wie, że czeka ją wyprawa do Petersburga $\mathrm{w}$ celu uwolnienia rodzicielki. Bohaterka, o czym dowiaduje się później, będzie też musiała zmierzyć się z polityczną niesprawiedliwością. Przykład z wilków ma brać uciśnione społeczeństwo rosyjskie, które winno stawiać opór wobec represyjnej władzy. Postawa potulna i oswojona jest w takim przypadku skazana na porażkę. Można uznać, że zadaniem Fieodory, która zajmuje się „odswajaniem” wilków, będzie też „odswajanie” społeczeństwa. Przypominając ludziom, że urodzili się po to, żeby być wolni, zagrzewa ich do walki i pośrednio zapoczątkowuje rewolucję․ Obraz dosłownego oswojenia

9 Przy odrobinie wiedzy z zakresu historii nietrudno powiązać pewne fakty i domyślić się, że Fieodora żyje w realiach rewolucji lutowej w Rosji. Nie chcąc dopuścić się nadinterpretacji, należy na wstępie zaznaczyć, że umiejscowienie powieściowych wydarzeń w czasie upadku 
wilka ma doprowadzić odbiorców do metaforycznej koncepcji oswojenia ludzi (w kontekście społeczno-kulturowym). Stąd też wynika stanowcza krytyka tego rodzaju praktyk.

Fizyczne oswojenie, polegające na przyzwyczajeniu dzikiego zwierzęcia do obecności człowieka, często wiąże się z oswojeniem w znaczeniu symbolicznym. Należy jednak pamiętać, że oba zjawiska mogą istnieć niezależnie. Niemożność fizycznego oswojenia dzikiego zwierzęcia, jakim jest wilk, najczęściej skutkuje oswojeniem symbolicznym, literackim. To ostatnie polega calkowicie na działalności człowieka i opiera się na redukcji niepożądanych cech, aby uzyskać łagodniejszą, a przez to sympatyczniejszą artystyczną reprezentację gatunku Canis lupus. Emilia Wieczorkowska (2014, s. 117-125) nazywa ten proces symboliczną domestykacją i w kontekście tego pojęcia odwołuje się do filmu animowanego Zakochany wilczek (Bell, Gluck, 2010), w którym wilczy bohaterowie zostają poddani nie tylko juwenalizacji, lecz także antropomorfizacji w celu zmniejszenia przepaści między tym, co ludzkie, a tym, co zwierzęce. W ten sposób granica na linii natura - kultura ulega zatarciu.

\section{Antropomorfizacja - przykład Czerwonej baśni}

Kiedy mówimy lub piszemy o zwierzętach, mamy tendencję do antropomorfizowania, czyli nadawania tym istotom cech ludzkich lub/i przypisywania im ludzkich intencji. Wiąże się to często ze zjawiskiem symbolicznej domestykacji, o którym wspominałam wyżej. Otrzymana w tekście przez zwierzęta, w tym przypadku wilki, zdolność mowy i poruszania się w sposób dwunożny jednocześnie bardzo ułatwia przeniesienie na nie wielu innych ludzkich przywar. Według Jerzego Cieślikowskiego (1975, s. 124) antropomorfizacja pozwala dzieciom zbliżyć się do zwierząt oraz poznać je w naturalny dla siebie sposób, właśnie poprzez wspomnianą antropomorfizację lub przez naśladownictwo. Choć obecnie antropomorfizacja bywa poddawana krytyce i, jako przypisywanie intencji innej żywej istocie, może być niezwykle problematyczna oraz skutkować brakiem zrozumienia potrzeb rzeczywistych, nie jest w całości odrzucana.

caratu wynika z odczytania wskazówek, które autorka pozostawia, nie mówiąc jednak wprost, w którym roku mają miejsce wydarzenia opisane w utworze, a także jak brzmi imię cara, który w nim występuje (jest on po prostu „carem”). Można stwierdzić, że jest to celowy zabieg Rundell. Pisze ona o prawdziwych wydarzeniach, splatając je z fikcją, aby wprowadzić młodego czytelnika w uniwersalny świat odwiecznych prawd. Powieść jedynie „zapożycza” pewne fakty z 1917 roku, aby móc przedstawić zjawiska ponadczasowe, takie jak walka z przeciwnościami losu oraz z trudnymi warunkami życia, walka o wolność czy spełnianie marzeń. 
Antropomorfizacja pełni w literaturze wiele funkcji, stanowi m.in. środek wyrazu artystycznego. Nowsze badania na gruncie animal studies wskazują zaś, że zjawisko to może stanowić próbę lepszego zrozumienia cech, zachowań i gestów zwierząt. Trudność w przyjęciu całkowicie zwierzęcej perspektywy nie musi bowiem oznaczać, że antropomorfizowanie jest „poszukiwaniem w zwierzęciu człowieczeństwa" (Kwapisz-Osadnik, 2011, s 35), a raczej może być wykorzystaniem człowieka jako modelu do zrozumienia zwierzęcego zachowania; antropomorfizacja nie jest w tym przypadku równoznaczna $\mathrm{z}$ antropocentryzmem. Warto przywołać tu stanowisko Marca Bekoffa (2013), referowane przez Barcz (2015): „[...] antropomorfizm nie unieważnia zwierzęcego punktu widzenia, a daje dostęp do emocji i zachowania zwierząt" (s. 176).

Godna przybliżenia w tym kontekście jest nowa, wydana w 2020 roku książka Czerwona baśń Wiktorii Korzeniewskiej. Warto zwrócić uwagę, że fabuła tego utworu, jak w Wilczerce Rundell, skupia się na dziewczynce, która niczym baśniowy Kapturek nosi czerwoną pelerynę. Na imię ma Gretel, tak samo jak Małgosia w niemieckiej wersji innej baśni, tym razem o Jasiu i Małgosi (niem. Hänsel und Gretel). Bohaterka Czerwonej baśni, jak nakazuje zwyczaj, wyrusza do lasu, gdzie czekać ma na nią tajemnicza postać, określana jako „Ta”. Niezwykła reinterpretacja znanych baśni, spleciona z motywami słowiańskimi, tworzy wyjątkową opowieść. W związku z tym, że książka pod względem fabularnym jest dosyć drastyczna i daleko jej do złagodzonych wersji tradycyjnej narracji, niezaprzeczalnie oddziałuje ona na wyobraźnię czytelnika, wzbudzając przerażenie, lęk, a nawet fascynację. Innowacyjne podejście do ukazania znanych historii poprzez zaskakująco zaprezentowane wydarzenia (ujawnienie przeszłości Tej, która odpowiada postaci Baby Jagi, czy specyficzna relacja wilka i Gretel) powoduje, że hipotetyczna publiczność czytelnicza może zadawać sobie pytanie o słuszność powszechnych opinii na temat poszczególnych bohaterów literackich. Propozycja Korzeniewskiej jest niezwykle symboliczna pod względem treściowym i dzięki temu daje ogromne pole do własnej analizy poszczególnych postaci i relacji między nimi. Czerwona baśń wykorzystuje motywy znane z wersji Grimmów (czerwona peleryna, Kapturek zbaczający ze ścieżki, wędrówka przez las do babci), historia jest jednak przedstawiona zgoła inaczej.

W Czerwonej baśni pojawia się wilk, którego kreacja stanowi znakomity przykład zarówno antropomorfizacji, jak i polemiki z dotychczasowym wzorcem wilka baśniowego (znanym z Czerwonego Kapturka oraz O wilku i siedmiu koźlątkach). Jako że dobro i zło, w przeciwieństwie do tego, jak ukazują je moralizatorskie bajki i baśnie, w powieści Korzeniewskiej zostają przedstawione nie jako dwubiegunowe aksjologicznie, a raczej jako niejednoznaczne 
i pozostawione do interpretacji czytelnika, również wilk okazuje się postacią wielowymiarową. Jest bardziej pomocnikiem głównej bohaterki aniżeli antagonistą. Widocznie antropomorfizowany, gdyż poruszający się na dwóch łapach, charakteryzujący się zdolnością mowy i ubrany w koszulę, posiada on mądrość godną starca, którą dzieli się z bohaterką, kiedy ta kilkukrotnie spotyka go na swojej drodze. Z głównego antagonisty-drapieżnika awansuje na godnego szacunku prastarego boga - Kościeja Nieśmiertelnego. Co więcej, wydaje się bardziej dystyngowany oraz opanowany niż w klasycznych wersjach baśni, np. Grimmowskich, w których wilk nie tylko budzi grozę, lecz także jawi się jako mało inteligentny. Wilk w Czerwonej baśni to także przeciwieństwo znanego już z literatury wizerunku wilka jako obżartucha czy kłamczucha (O wilku i siedmiu koźlątkach, Trzy małe świnki) dającego się łatwo oszukać, a jeszcze łatwiej - wyprowadzić z równowagi. Ujawnia to, iż kulturowy (a jednocześnie stereotypowy) Canis lupus został w klasycznych narracjach „skrzywdzony” na dwa sposoby: ukazywany bywał jako, po pierwsze, symbol zła, a po drugie jako stworzenie gapowate, w dodatku próżne.

Według Anny Nosek (2019, s. 53) wilk stopniowo, w miarę pojawiania się nowych interpretacji baśni (i nowych tekstów literackich w ogóle), zyskuje pozytywną aksjologię. Jego kulturową „wędrówkę" badaczka określiła jako drogę „od degradacji do afirmacji” (s. 56) - Wilczerka i Czerwona baśń to przykłady utworów, które potwierdzają tę tezę.

\section{Zakończenie}

Próba opisu rzeczywistości językiem świata przyrody skłania nas do przypisywania zwierzętom, a więc istotom nam najbliższym, cech, które tylko po części wynikają z ich natury, w większej zaś części są naszą interpretacją, dokonaną przez pryzmat tego, jacy jesteśmy jako ludzie. Kształt kulturowej wizji gatunku Canis lupus pozwala na obsadzenie wilka w roli przewodnika dziecięcego bohatera literackiego, stojącego u progu dorosłości. Analizowane teksty ujawniają, że cechy (współcześnie) kulturowo utożsamiane z wilkiem, jak odwaga i wolność, jednocześnie stanowią ogromną wartość - nie tylko dla ludzi jako jednostek, lecz także dla społeczeństw. Dopóki wilk będzie się kojarzyć właśnie z tymi właściwościami, dopóty jego reputacja nie ucierpi, a dawniejsze, stereotypowe zarzuty mają szansę zostać kulturowo wyparte.

Niniejszy artykuł stanowił próbę wyjścia poza perspektywę antropocentryczną w celu analizy przekształceń, którym poddawany jest wilk w wybranych dziełach literatury dziecięcej i młodzieżowej. Utwory, które zostały 
przywołane jako egzemplifikacje, pozwalają ustalić specyfikę literackich reprezentacji gatunku Canis lupus, zasadzającą się na koncepcie, że w powieściach dziecięcych i młodzieżowych, inaczej niż np. w baśniach tradycyjnych, stanowi on doskonałe ogniwo łączące bohatera (a zarazem utożsamiającego się z nim czytelnika) ze światem, w który ma wkroczyć taka postać (i w który wkracza czytelnik dzięki lekturze). Omówione dzieła dowodzą też, że choć oczywiście recepcja Canis lupus zmienia się w zależności od miejsca i czasu, zmieniamy się przede wszystkim my jako twórcy i odbiorcy kultury.

\section{Bibliografia}

Barcz, A. (2015). Relacja człowieka i zwierzęcia w noweli Wilk, psy i ludzie Dygasińskiego. W: E. Łoch, A. Trześniewska, D. Piechota (red.), Emancypacja zwierząt? (s. 165-177). LTN.

Baluch, A. (1993). Archetypy literatury dziecięcej. Wacław Bagiński i Synowie.

Bekoff, M. (2013). Animal consciousness and science matter: Anthropomorphism is not anti-science. Relations: Beyond Anthropocentrism, 1(1), 61-68. https://doi. org/10.7358/rela-2013-001-beko.

Bell, A., Gluck, B. (reż.). (2010). Alpha and Omega [Zakochany wilczek] [film]. Crest Animation Productions, Lionsgate Films.

Bright, R., Field, J. (2019). Wilk, który się zgubił (B. Supeł, tłum.). Zielona Sowa. (wyd. oryg. 2018).

Brzechwa, J. (2014). Zoo. Skrzat. (wyd. oryg. 1938).

Cieślikowski, J. (1975). Literatura i podkultura dziecięca. Zakład Narodowy im. Ossolińskich.

Curwood, J. O. (1961). Szara Wilczyca (J. Marlicz, tłum.). Iskry. (wyd. oryg. 1914).

Dziki. (b.d.). Słownik sjp.pl. Pobrane 21 grudnia 2020 z: https://sjp.pl/dziki.

Grimm, W., Grimm, J. (2010a). Czerwony Kapturek. W: Baśnie dla dzieci i dla domu (E. Pieciul-Karmińska, tłum., t. 1, s. 147-151). Media Rodzina. (wyd. oryg. 1857).

Grimm, W., Grimm, J. (2010b). O wilku i siedmiu koźlątkach. W: Baśnie dla dzieci i dla domu (E. Pieciul-Karmińska, tłum., t. 1, s. 25-37). Media Rodzina. (wyd. oryg. 1857).

Jans, N. (2016). Wilk zwany Romeo (A. Pluszka, tłum.). Marginesy. (wyd. oryg. 2014).

Katherine Rundell. (b.d.). Poradnia K. Pobrane 21 grudnia 2020 z: https://sklep.poradniak.pl/blog/autorzy/katherine-rundell.

Kipling, R. (2005). Księga dżungli (A. Dziarmaga, tłum.). Arkady. (wyd. oryg. 1894).

Korzeniewska, W. (2020). Czerwona baśńn. Aniversum. 
Kwapisz-Osadnik, K. (2012). „Jak pies z kotem”, czyli o stereotypach w języku. W: J. Kurek, K. Maliszewski (red.), Zwierzęta i ludzie (s. 31-39). MDK Batory.

London, J. (2006). Biały Kieł (M. Golewska-Stafiej, tłum.). Rytm, Waza. (wyd. oryg. 1906).

Mikołuszko, W. (2016, 26 kwietnia). Biologia baśni. Czerwony Kapturek traci niewinność. Wyborcza.pl. Pobrane 21 grudnia 2020 z: https://wyborcza. pl/1,145452,19974647,biologia-basni-czerwony-kapturek-traci-niewinnosc.html.

Mittermeier, R. A., Mittermeier, C. G., Brooks, T. M., Pilgrim, J. D., Konstant, W. R., da Fonseca, G. A. B., Kormos, C. (2003). Wilderness and biodiversity conservation. Proceedings of the National Academy of Sciences, 100(18), 10309-10313. https://doi. org/10.1073/pnas.1732458100.

Nikodem, M. (2014). Tańczący z wilkami, biegnąca z wilkami. Próba Ricoeurowskiej analizy symbolu wilka. W: D. Wężowicz-Ziółkowska, E. Wieczorkowska (red.), K. Jaglarz (współpr. red.), Wilki i ludzie. Małe kompendium wilkologii (s. 271-286). Grupa Kulturalna.

Nosek, A. (2019). Przemiany symboliki wilka w literaturze dziecięcej. Ars Inter Culturas, 8, 53-66. https://doi.org/10.34858/AIC.8.2019.003.

Nowak, S., Mysłajek, R. (2019). Po sąsiedzku z wilkami. Stowarzyszenie dla Natury „Wilk”.

Oswoić. (b.d.). Słownik sjp.pl. Pobrane 21 grudnia $2020 \mathrm{z}$ : https://sjp.pl/oswoić.

Parry, R. (2019). A wolf called Wander. Greenwillow Books.

Piechota, D. (2018). Pozytywistów spotkania z naturą. Szkice ekokrytyczne. WN Katedra.

Rąbkowska, E. (2016). „Śmieciowe” zwierzęta (trash animals) i „dzieci śmieci”. Relacje dziecka i zwierzęcia w literaturze dla dzieci i młodzieży. W: A. Mik, P. Pokora, M. Skowera (red.), Czytanie menażerii. Zwierzęta $w$ literaturze dziecięcej, młodziezowej i fantastycznej (s. 31-51). Wydawnictwo SBP.

Rąbkowska, E. (2017). Dzieci, zwierzęta i wielka zabawa. Przekształcenia wątków zwierzęcego folkloru w polskiej literaturze dla dzieci i młodzieży w perspektywie kulturowych studiów nad zwierzętami (cultural animal studies). Polonistyka. Innowacje, 5, 85-99. https://doi.org/10.14746/pi.2017.1.5.8.

Rundell, K. (2019). Wilczerka (P. Braiter, tłum.). Poradnia K. (wyd. oryg. 2015).

Sieroń, A. (2005). Wilk i wilkołak w kulturze. Anthropos?, 4-5. Pobrane 21 grudnia $2020 \mathrm{z}$ : http://www.anthropos.us.edu.pl/anthropos3/teksty/tekstB5.htm.

Skowera, M. (2016). Literackie spotkania istot podporządkowanych. Studium przypadku: Miasteczko Ostatnich Westchnień Grzegorza Gortata. W: A. Mik, P. Pokora, M. Skowera (red.), Czytanie menażerii. Zwierzęta $w$ literaturze dziecięcej, młodzieżowej i fantastycznej (s. 53-74). Wydawnictwo SBP.

Slany, K. (2016a). Groza w literaturze dziecięcej. Od Grimmów do Gaimana. WN UP. 
Slany, K. (2016b). Orbis exterior w baśni magicznej i jego symbolika w Oblubienicy Tygrysa i Towarzystwie wilków Angeli Carter. W: W. Kostecka, M. Skowera (red.), Geografia krain zmyślonych. Wokół kategorii miejsca i przestrzeni w literaturze dziecięcej, młodzieżowej i fantastycznej (s. 269-286). Wydawnictwo SBP.

Tuan, Y.-F. (2007). Animal pets: Cruelty and affection. W: L. Kalof, A. Fitzgerald (red.), The animal reader: The essential classic and contemporary writings (s. 141-153). Berg. (wyd. oryg. 1984).

Wagener, G. (2007). Wilczek (M. Wróbel-Lutz, tłum.). Tatarak. (wyd. oryg. 1993).

Wieczorkowska, E. (2014). Canis lupus w sidłach popkultury. W: D. Wężowicz-Ziółkowska, E. Wieczorkowska (red.), K. Jaglarz (współpr. red.), Wilki i ludzie. Małe kompendium wilkologii (s. 115-132). Grupa Kulturalna. 